\title{
Sonographic diagnosis of true neurogenic thoracic outlet syndrome
}

Figure Imaging findings in true neurogenic thoracic outlet syndrome
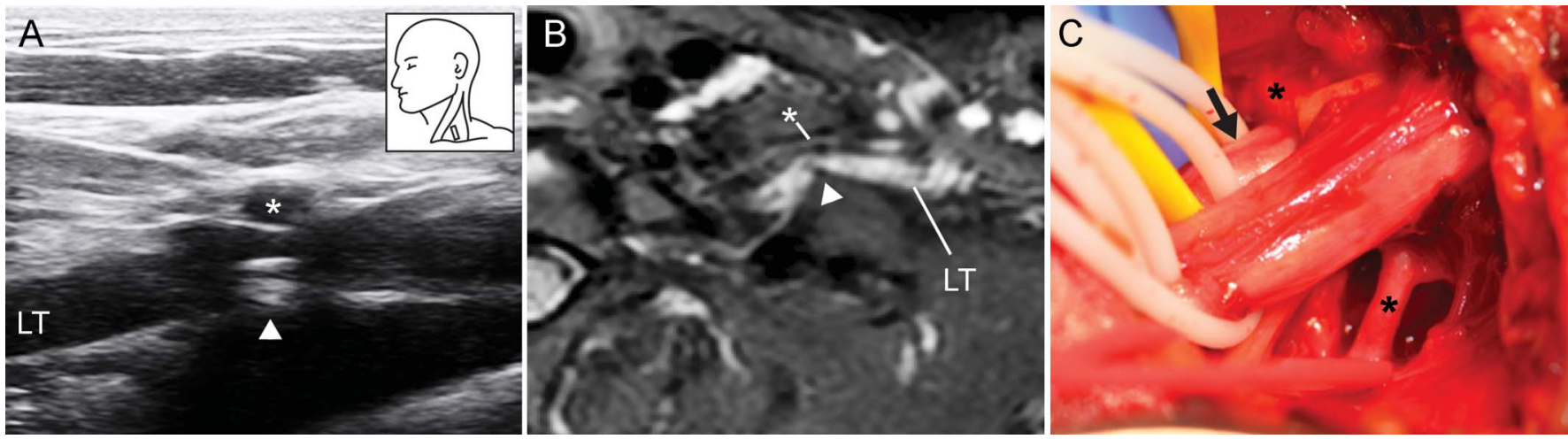

Correlation between ultrasound (A) and MRI (B) demonstrates compression of the lower trunk (LT) between an artery ( $\left(^{*}\right)$ and fibrous band (arrowhead) arising from an elongated $\mathrm{C} 7$ transverse process. At operation $(C)$, the artery $\left({ }^{*}\right)$ passed between the middle and lower trunks. Fibrous bands were resected to release the LT (arrow).

A 32-year-old woman presented with a 5-year history of left shoulder pain, medial hand and forearm numbness, and progressive hand weakness and atrophy. Electrodiagnostic studies were characteristic of true neurogenic thoracic outlet syndrome, ${ }^{1}$ and a chest $\mathrm{x}$-ray showed bilateral elongated C7 transverse processes. High-resolution ultrasound studies revealed compression of the left lower trunk (LT) between a fibrous band and artery (figure, A). Magnetic resonance neurography (figure, B) and operative exploration (figure, C) confirmed the ultrasound findings. Clinical improvement was noted following surgical neurolysis of the LT. High-resolution ultrasound may be a useful and quick bedside tool to identify causative structural pathology in this classic neuromuscular disorder.

Neil G. Simon, MBBS, FRACP, Jeffrey W. Ralph, MD, Cynthia Chin, MD, Michel Kliot, MD

From the University of California, San Francisco.

Author contributions: Dr. Simon: study design, data acquisition and analysis, drafting and critical revision of the manuscript. Dr. Ralph: data acquisition and analysis, critical revision of the manuscript for important intellectual content. Dr. Chin: data acquisition and analysis, critical revision of the manuscript for important intellectual content. Dr. Kliot: study design, data acquisition and analysis, critical revision of the manuscript for important intellectual content.

Study funding: Dr. Simon acknowledges funding from the National Health and Medical Research Council and the Motor Neurone Disease Research Institute of Australia (grant 1039520).

Disclosure: The authors report no disclosures relevant to the manuscript. Go to Neurology.org for full disclosures.

Correspondence to Dr. Simon: n.simon@unsw.edu.au

1. Wilbourn AJ. The thoracic outlet syndrome is overdiagnosed. Arch Neurol 1990;47:328-330. 


\section{Neurology}

\section{Sonographic diagnosis of true neurogenic thoracic outlet syndrome Neil G. Simon, Jeffrey W. Ralph, Cynthia Chin, et al. Neurology 2013;81;1965 \\ DOI 10.1212/01.wnl.0000436621.33155.ed}

This information is current as of November 25, 2013

\section{Updated Information \& Services}

\section{References}

Citations

Subspecialty Collections

Permissions \& Licensing

Reprints including high resolution figures, can be found at: http://n.neurology.org/content/81/22/1965.full

This article cites 1 articles, 0 of which you can access for free at: http://n.neurology.org/content/81/22/1965.full\#ref-list-1

This article has been cited by 1 HighWire-hosted articles: http://n.neurology.org/content/81/22/1965.full\#\#otherarticles

This article, along with others on similar topics, appears in the following collection(s):

EMG

http://n.neurology.org/cgi/collection/emg

MRI

http://n.neurology.org/cgi/collection/mri

Peripheral nerve trauma

http://n.neurology.org/cgi/collection/peripheral_nerve_trauma Ultrasound

http://n.neurology.org/cgi/collection/ultrasound

Information about reproducing this article in parts (figures,tables) or in its entirety can be found online at:

http://www.neurology.org/about/about_the_journal\#permissions

Information about ordering reprints can be found online:

http://n.neurology.org/subscribers/advertise

Neurology ${ }^{\circledR}$ is the official journal of the American Academy of Neurology. Published continuously since 1951, it is now a weekly with 48 issues per year. Copyright @ 2013 American Academy of Neurology. All rights reserved. Print ISSN: 0028-3878. Online ISSN: 1526-632X.

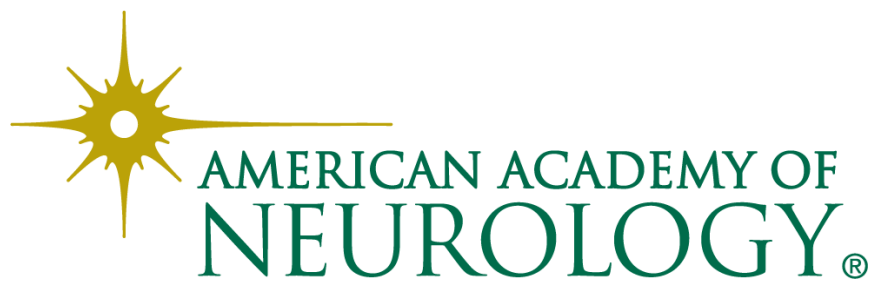

